\title{
Was intervention in Iraq legally justified?
} by Khawar Qureshi

\author{
The question posed by this article is whether the Security Council \\ of the United Nations provided legal authority for the current \\ intervention in Iraq.
}

$\mathrm{T}$ he United Nations was born in the aftermath of the Second World War with the aim of curtailing use of force and promoting common goals. It is now strongly arguable that force cannot be used by a state except in the following circumstances:

- Self defence and assisting a state where an armed attack has taken place;

- Neutralising the threat posed by an imminent armed attack;

- Responding to a gross violation of human rights - such a genocide;

- Pursuant to authorisation by the Security Council (in accordance with Arts 39 and 42 of the UN Charter).

However, the ability of just one permanent member to enfeeble the Security Council (SC) by casting a negative vote was a dominant feature of Cold War politics. This is, and always has been, an intrinsic part of the UN system (as per Art 27 of the UN Charter). It reflects the fact that the $\mathrm{SC}$ is a political body. Indeed, it is worth remembering that the SC has rarely acted with unanimity.

Nevertheless, after the collapse of the Soviet Union, the permanent members of the SC were anxious to show the international community that they could be united. The concept of the "new world order" was being heralded as an era in which maintenance of world peace and security was at the core. This provided the context within which the SC considered the invasion of Kuwait by Iraq in 1990 .

\section{IRAQ SECURITY COUNCIL RESOLUTIONS}

In resolution 678 of 1990 , the SC authorised member states to use "all necessary means" to uphold and implement its resolutions condemning the invasion, and to restore international peace and security in the area.

The SC imposed detailed obligations on Iraq in resolution 687 of 1991 as a necessary step for achievement of its stated objective of restoring international peace and security in the area. Both of these resolutions were passed unanimously under Chapter VII of the UN Charter. That meant that the resolutions were binding on all member states of the UN (Article 25 of the UN Charter).

We need to remember that Security Council Resolutions ("SCR's") cannot be interpreted like English legislation or a Treaty. The context of SCR's and their long term aims are of fundamental significance. The resolutions identified above demanded that Saddam Hussein's regime must comply with its obligations under international law. These included very clearly defined disarmament obligations. It is wrong to say they were limited to matters concerning Kuwait. The Security Council was manifestly taking a long term view, and that is why it imposed obligations to neutralise the future threat that Saddam Hussein's regime could pose to other states in the region, and consequently to international peace and security.

It is also clear that the Security Council has never declared that Saddam Hussein's regime no longer poses a threat to international peace and security - on the contrary. It has also never formally revoked the authorisation for states to "use all necessary means" to respond to the threat posed. The fact that Resolution 678 was never formally revoked is because of the persistent non-compliance by Saddam Hussein's regime, and the threat to international peace and security this continues to pose.

\section{RESOLUTION 1441}

SC Resolution 1441 was negotiated over a period of eight weeks and passed unanimously on 8 November 2002. Inter alia, SCR 1441:

- Expressly recalled (and thus re-affirmed) the abovementioned resolutions (678 and 687);

- Declared that Iraq was in breach of its disarmament obligations;

- Gave a deadline of 30 days for a full and complete declaration of the Iraqi weapons programme;

- Warned of serious consequences if there was further non- compliance by Iraq in this regard. 
If the SC had intended to reserve to itself the right to authorise force by means of a further resolution, it could obviously have done so. Indeed this approach was discussed informally by members of the Security Council but never became the subject of a draft resolution or vote; see Hansard, 25 November 2002 at page 53 (per the Foreign Secretary).

The SC could also have qualified its reference to resolutions 678 and 687, and thus made it clear that member states could not use force to deal with the threat posed to peace and security by Iraq. It did not do so. The fact that there is now some disagreement as to what was meant by SCR 1441 cannot prevent the words of that resolution (or indeed the earlier resolutions) from carrying their plain and ordinary meaning.

\section{CONCLUSION}

The use of necessary and proportionate force, in accordance with international humanitarian law by coalition forces, to neutralise the threat posed by Saddam Hussein's failure to comply with UN imposed disarmament obligations can be rooted in:

- SCR 678 (authority to use force);

- SCR 687 (the requirement for the Iraqi regime to, inter alia, disarm so as to remove the threat to international peace and security it posed);
- SCR 1441 (confirmation of SCR's 678, 687, and of the fact that Iraq's continued non-compliance with disarmament obligations triggered serious consequences).

Post intervention, emerging issues are likely to include the following:

- Possible attempts to challenge the intervention at the International Court of Justice (compare with the attempt to challenge the NATO action in Kosovo in March 1999);

- Possible attempts to persuade the DPP to carry out a "war crimes" investigation in the event that UK forces bomb civilian targets and/or an argument can be made to this effect;

- War crimes trials/asset freezing action in respect of Saddam and/or his accomplices;

- Security Council interaction on humanitarian issues and post conflict issues in Iraq - potential for other states to use this as a platform to condemn the intervention and/or using this to effect "retrospective legitimacy". 숭

\section{State protection of the child - mirage or reality?}

by Dr Ya'ir Ronen

My central point in this article is that state protection of the child as projected by the legal rhetoric of child protection law is a mirage in that it gives the misleading impression of comprehensive protection to the child from all harm while typically failing to offer such protection.

$I^{2}$ base my view on child protection on an analysis of domestic legislation and case law in several domestic jurisdictions. It is important to clarify at the outset that I can only attempt to convince the reader of a general pattern of distortion and that different legal systems differ in the degree of compatibility between the reality of child
My thesis is based around the following six complementary claims:

1. Child protection law is typically perceived through its aims and mandates as offering the child comprehensive protection from all harm.

2. These aims and mandates disguise a preoccupation 